\title{
In Vitro Selection of Foeniculum vulgare for Salt Tolerance
}

\author{
Rozita KHORAMI ${ }^{1}$, Abbas SAFARNEJAD² \\ ${ }^{1}$ Islamic Azad University of Mashhad, Departament of Plant Physiology, Iran; rozitakhorrami@yahoo.com \\ ${ }^{2}$ Razavi Khorasan Agricultural and Natural Resources Research Center, 1148/91735, Mashhad, Iran; sebre14@yahoo.com (corresponding author)
}

\begin{abstract}
In vitro selection of Foeniculum vulgare for salt tolerance was undertaken by the use of somaclonal variation. In this idea, explants of root, hypocotyl and cotyledon of sterilized seedling were transferred to callus and regeneration media with concentrations of 0,50 , 100 and $150 \mathrm{mM}$ of $\mathrm{NaCl}$. After 4 weeks, calli induction, regeneration frequency and calli fresh and dry weights, in both control and stress conditions, were measured. The results showed that salinity caused a significant decrease in the callus induction and shoot regeneration of fennel. However, in the presence of 100 and $150 \mathrm{mM} \mathrm{NaCl}$, the highest frequency of callus induction in hypocotyl and cotyledon explants was recorded on the media supplemented with $1 \mathrm{mgl}^{-1} \mathrm{IAA}$ (Indol-3-Acetic Acid) plus $1 \mathrm{mg} \mathrm{l}^{-1}$ 2,4-D (2, 4- dichlorophenoxyacetic acid) and $2 \mathrm{mg} \mathrm{l}^{-1}$ kinetin. Among different growth regulator treatments, the combination of $2 \mathrm{mg} \mathrm{l}^{-1} \mathrm{NAA}$ (Naphtaleneacetic acid) and 0.5 $\mathrm{mg} \mathrm{l}^{-1}$ kinetin was found to be the most effective for shoot regeneration under stress condition. The highest dose of $\mathrm{NaCl}(150 \mathrm{mM})$ inhibited callus induction and shoot regeneration compared to control with $41 \%$ and $96 \%$ respectively. The calli fresh and dry weights of all explants were decreased with the increas of $\mathrm{NaCl}$ concentration. The highest and the lowest of dry and fresh weight of calli were observed in 0 and $150 \mathrm{mM}$ respectively.
\end{abstract}

Keywords: calli induction, Foeniculum vulgare, in vitro selection, regeneration, salinity

Abbreviations: IAA: Indol-3-acetic acid; 2,4-D: 2,4-dichlorophenoxy acetic acid; NAA: $\alpha$-Naphthalene acetic acid

\section{Introduction}

Fennel (Foeniculum vulgare Mill.) is one of the oldest medicinal plants, used for pharmaceutical, food, hygienic and cosmetic industries. Fennel is an annual, biennial or perennial plant, depending on the variety, belonging to Apiaceae family and is native to the Mediterranean area (Piccaglia and Marotti, 2001). It has been cultivated and introduced into many regions outside that zone; it is grown commercially in some of them, such as Russia, India, China and Japan (Damjanovic et al., 2005).

In vitro technology, especially plant tissue culture offers many unconventional techniques for crop improvement (Dennis Thomas and Sreejesh, 2004). In vitro culture of plant cells and tissue has attracted considerable interest over the recent years because it provides the means to study the physiological and genetic processes of plants in addition of offering the potential to assist in breeding improved cultivars by increasing the genetic variability (Benderradji et al., 2007). According to Larkin and Scowcroft (1981) it is now generally accepted that plant cell culture itself generates genetic variability increasing cell mutation frequency. Genetic factors are considered to be a major contributor to the in vitro response of cultured tissues. Differences in the production of calli and regenerated plantlets have been observed, depending on the genotype and the source of explant (Ganeshan et al., 2003). Also, the composition of the media mainly the hormonal balance is another important factor influencing in vitro culture initiation and plant regeneration (Jiang et al., 1998). Plant tissue culture techniques provide a promising approach to develop salt tolerant plants (Gandonou et al., 2005). This method is based on the induction of genetic variation among cells, tissues and/or organs in cultured and regenerated plants (Mohamed et al., 2000). Breeding for environmental stress tolerance by traditional methods is a time consuming and inefficient procedure (Dorffling et al., 1993). In vitro selection of salt tolerant cell lines and regenerated plants has been reported in several species such as potato (Sabbah and Tal, 1990), rice (Lutts et al., 1999), hordeum (Sibi and Fakiri, 2000), wheat (Barakat and Abdel-latif, 1996), sunflower (Alvarez et al., 2003) and alfalfa (Safarnejad et al., 1996). This suggests that tissue culture selection can be used to improve salt tolerance in plants (Gandonou et al., 2005).

Salinity is one of the most important environmental stresses that reduces of growth, development and production of plants. The major inhibitory effect of salinity on plant growth and yield has been attributed to osmotic effect, ion toxicity and nutritional imbalance leading to reduction in photosynthetic efficiency and other physiological disorders (Mahajan and Tutija, 2005; Zhu, 2007; Yokoi et al., 2002). Salinity is the main abiotic stress that has been addressed by in vitro selection, and applications 
to other stresses such as heat and drought have also been reported (Lutts et al., 1996; Safarnejad, 2004). Currently, these techniques are considered to be an important complement to classical breeding methods (Zalc et al., 2004).

The regeneration of plants displaying an increased tolerance to environmental stress is an important goal for the biotechnological improvement of many plant species (Mohamed et al., 2000); therefore the purpose of this experiment was to induce somaclonal variation in regenerated plants in order to select $\mathrm{NaCl}$-tolerant callus line of Foeniculum vulgare using in vitro regeneration protocol. Hence, callus induction, regeneration frequencies and rate of growth of root, hypocotyl and cotyledon explants of Foeniculum vulgare in populations of Esfahan, were tested under salinity stress conditions.

\section{Materials and methods}

\section{Plant material and growth condition}

The experiment was conducted in the Tissue Culture Laboratory of Razavi-Khorasan Agriculture and Natural Reasources Research Center during the years 2006-2007. Seeds of Esfahan populations of Foeniculum vulgare were used in the present experiment. At first, seeds were surface sterilized for $10 \mathrm{~min}$. in $20 \%$ sodium hypochlorite, then rinsed three times with sterilized distilled water. After disinfection, the seeds were placed on MS (Murashing and Skoog, 1962) basal medium supplemented with 30 $\mathrm{g} \mathrm{L}^{-1}$ sucrose and $8 \mathrm{~g} \mathrm{~L}^{-1}$ agar. The medium was adjusted to $\mathrm{pH} 5.7$ before autoclaving at $121^{\circ} \mathrm{C}$ for $20 \mathrm{~min}$ at 1.16 $\mathrm{kg} \mathrm{cm}^{-1}$ pressure. The cultures were incubated in growth chamber under both dark $(8 \mathrm{~h})$ and light $(16 \mathrm{~h})$ condition. The temperature was maintained at $25^{\circ} \mathrm{C}$. After 5-6 days, seeds were germinated on these media. Root, hypocotyl and cotyledon of 9 days old seedling of Foeniculum vulgare were used as explants in the present experiment.

\section{Callus induction and plant regeneration}

For callus induction and regeneration, root, hypocotyl and cotyledon explants (10 mm long) were placed on MS medium (Murashige and Skoog, 1962) supplemented with $30 \mathrm{~g} \mathrm{~L}-1$ sucrose and $8 \mathrm{~g} \mathrm{~L}^{-1}$ agar and the following growth regulator combinations: (I) $1 \mathrm{mgl}^{-1}$ IAA plus $1 \mathrm{mg}$ $\mathrm{l}^{-1} 2,4-\mathrm{D}$ and $2 \mathrm{mg} \mathrm{l}^{-1}$ kinetin (II) $2 \mathrm{mg} \mathrm{l}^{-1} \mathrm{NAA}$ and $0.5 \mathrm{mg}$ $\mathrm{l}^{-1}$ kinetin (III) $0.5 \mathrm{mg} \mathrm{l}^{-1} \mathrm{NAA}$ and $0.5 \mathrm{mg}^{-1}$ kinetin (IV) $0.5 \mathrm{mg} \mathrm{l}^{-1} \mathrm{NAA}$ and $2 \mathrm{mg} \mathrm{l}^{-1}$ kinetin.

After four weeks of incubation, the induced calli were subcultured, under the same growth conditions and in the same MS medium for shoot and root initiation. Also the regenerating calli, showing shoot formations, were transferred to the MS basal medium supplemented with $30 \mathrm{~g}$ $\mathrm{L}^{-1}$ sucrose, $8 \mathrm{~g} \mathrm{~L}^{-1}$ agar, for root formation and placed in the growth chamber for another four-week period. Then the number of explants producing callus and the number of shoot regeneration from each explants were counted. The frequency of callus induction and shoot regeneration were calculated by dividing the number of calli and shoot regeneration to the original number of plated explants.

\section{In vitro sodium chloride treatments}

Explants of root, hypocotyl and cotyledon were cultured on MS medium containing $1 \mathrm{mg} \mathrm{l}^{-1}$ IAA, $1 \mathrm{mg} \mathrm{l}^{-1}$ 2,4-D and $2 \mathrm{mg} \mathrm{l}^{-1}$ kinetin (media I) with 0, 50, 100 and $150 \mathrm{mM}$ of $\mathrm{NaCl}$. On the other hand, explants were transferred to MS medium containing $2 \mathrm{mg} \mathrm{l}^{-1} \mathrm{NAA}$ and 0.5 $\mathrm{mg} \mathrm{l}^{-1}$ kinetin (media II) with different concentrations of $\mathrm{NaCl}$. After 4 weeks, callus induction rate, fresh and dry weight of different explants were measured. In order to study the ability of different explants to regeneration shoots on medium containing $\mathrm{NaCl}$, the induced calli from both medium were placed on the same medium composition to which various concentrations $\mathrm{NaCl}(0,50,100$ and $150 \mathrm{mM}$ ) were added. The incubation period lasted 28 days. Finally, the $\mathrm{NaCl}$ tolerant regenerating calli, were transferred on to the MS basal medium with no growth regulators for root formation.

The data were obtained on callus induction efficiency, measured as the number of calli/total number of explants $x$ 100 , and the regeneration efficiency as the number of regenerated shoots/total number of calli $\times 100$.

The fresh weight for callus of different explants (root, hypocotyl and cotyledon) were assessed, and for the determination of dry weight the callus was dried for 3 days in an oven at $70^{\circ} \mathrm{C}$.

\section{Statistical analysis}

This experiment has been carried out in a completely randomized design with 12 treatment and 15 replications per treatment. Statistical significance between mean values was assessed using the analysis of variance and a conventional Duncan,s multiple range test using SAS Statistical software (SAS Institute, 1992). A probability of $\mathrm{p}<0.05$ was considered significant.

\section{Results}

\section{Callus induction and regeneration under non-stress} condition

Callus induction and shoot regeneration were observed on MS medium supplemented with different treatments, two and four weeks after transferring explants to medium, respectively. One hundred percent of the fennel hypocotyl and cotyledon explants formed callus during the first month of culture on all mediums. The maximum size of callus formed on the medium containing $1 \mathrm{mg} \mathrm{l}^{-1}$ IAA plus $1 \mathrm{mg} \mathrm{l}^{-1}$ 2,4-D and $2 \mathrm{mg} \mathrm{l}^{-1}$ kinetin (media I). The produced calluses on this media were large and green (Fig. 1). Also, dark-green and large calluses were produced in the medium with $2 \mathrm{mg} \mathrm{l}^{-1} \mathrm{NAA}$ and $0.5 \mathrm{mg} \mathrm{l}^{-1}$ kinetin, whereas in other media, the color of the calluses turned into yellow or white and their size was too small. A good response for shoot regeneration was observed only in the 
92

Tab. 1. Analysis of variance for studied traits of Foeniculum vulgare on MS medium

\begin{tabular}{ccccc}
\hline $\begin{array}{c}\text { Rooting } \\
\text { frequency } \\
(\%)\end{array}$ & $\begin{array}{c}\text { Shoot } \\
\text { regeneration } \\
\text { frequency } \\
(\%)\end{array}$ & $\begin{array}{c}\text { Callus } \\
\text { induction } \\
\text { frequency } \\
(\%)\end{array}$ & $\begin{array}{c}\text { Degrees } \\
\text { of } \\
\text { freedom }\end{array}$ & $\begin{array}{c}\text { Source of } \\
\text { variation }\end{array}$ \\
\hline $817.75^{* *}$ & ${ }^{* *} 2686.72$ & $3015.34^{* *}$ & 11 & Treatment \\
\hline $2743.50^{* *}$ & ${ }^{* *} 4018.61$ & $515.02^{* *}$ & 3 & Media \\
$95.76^{*}$ & ${ }^{* *} 6149.53$ & $14266.79^{* *}$ & 2 & $\begin{array}{c}\text { Explant } \\
95.53^{*}\end{array}$ \\
${ }^{* *} 866.50$ & $515.02^{* *}$ & 6 & $\begin{array}{c}\text { Media } \times \\
\text { Explan }\end{array}$ \\
20.40 & 25.68 & 5.95 & 36 & Error \\
\hline
\end{tabular}

${ }^{*}, * *$ Significant difference at 0.05 and 0.0 .1 probability level, respectively

case of the 4:1 NAA/kinetin ratio (on the medium containing $2 \mathrm{mg} \mathrm{l}^{-1} \mathrm{NAA}$ and $0.5 \mathrm{mg} \mathrm{l}^{-1}$ kinetin) and this medium was the best for callus induction, shoot regeneration and rooting simultaneously (Fig. 2). The results showed significant effects of treatments on callus induction and shoot regeneration (Tab. 1). The highest rates of callus induction, shoot regeneration and rooting were observed in the explants of cotyledon. There was significant difference between explants on callus induction and shoot regeneration (Tab. 1). Because, only green calluses have the capability to transfer to other processes of experiment, therefore two media including MS medium containing $1 \mathrm{mgl}^{-1} \mathrm{IAA}$ plus $1 \mathrm{mg} \mathrm{l}^{-1}$ 2,4-D and $2 \mathrm{mg} \mathrm{l}^{-1}$ kinetin (media I) and MS medium with $2 \mathrm{mg} \mathrm{l}^{-1} \mathrm{NAA}$ and $0.5 \mathrm{mg} \mathrm{l}^{-1}$ kinetin (media II) was selected for salinity treatments.

Tab. 2. Means comparison of different explants of Foeniculum vulgare under salinity stress

\begin{tabular}{ccccc}
\hline $\begin{array}{c}\text { Dry } \\
\text { weight } \\
\text { of callus } \\
(\mathrm{mg})\end{array}$ & $\begin{array}{c}\text { Fresh } \\
\text { weight of } \\
\text { callus }(\mathrm{mg})\end{array}$ & $\begin{array}{c}\text { Shoot } \\
\text { regeneration } \\
\text { frequency } \\
(\%)\end{array}$ & $\begin{array}{c}\text { Callus } \\
\text { induction } \\
\text { frequency } \\
(\%)\end{array}$ & Explant \\
\hline $5.63 \mathrm{a}$ & $72.36 \mathrm{a}$ & $37.03 \mathrm{a}$ & $93.34 \mathrm{a}$ & Cotyledon \\
$4.27 \mathrm{~b}$ & $59.36 \mathrm{~b}$ & $13.91 \mathrm{~b}$ & $87.81 \mathrm{~b}$ & Hypocotyl \\
$1.63 \mathrm{c}$ & $25.76 \mathrm{c}$ & $4.38 \mathrm{c}$ & $29.91 \mathrm{c}$ & Root \\
\hline
\end{tabular}

Different letters indicate significant difference between means at $\mathrm{P}<0.05$.

Tab. 3. Means comparison of different treatments of salinity in Foeniculum vulgare

\begin{tabular}{ccccc}
\hline $\begin{array}{c}\text { Dry weight } \\
\text { of callus } \\
(\mathrm{mg})\end{array}$ & $\begin{array}{c}\text { Fresh } \\
\text { weight } \\
\text { of callus } \\
(\mathrm{mg})\end{array}$ & $\begin{array}{c}\text { Shoot } \\
\text { regeneration } \\
\text { frequency } \\
(\%)\end{array}$ & $\begin{array}{c}\text { Callus } \\
\text { induction } \\
\text { frequency } \\
(\%)\end{array}$ & $\begin{array}{c}\text { Salinity } \\
(\mathrm{mM})\end{array}$ \\
\hline $6.13 \mathrm{a}$ & $96.74 \mathrm{a}$ & $35.83 \mathrm{a}$ & $84.17 \mathrm{a}$ & Control \\
$4.6 \mathrm{~b}$ & $61.2 \mathrm{~b}$ & $26.04 \mathrm{~b}$ & $83.75 \mathrm{a}$ & 50 \\
$2.7 \mathrm{c}$ & $31.8 \mathrm{c}$ & $10.42 \mathrm{c}$ & $63.71 \mathrm{~b}$ & 100 \\
\hline $1.95 \mathrm{~d}$ & $20.23 \mathrm{~d}$ & $1.46 \mathrm{~d}$ & $49.79 \mathrm{c}$ & 150 \\
\hline
\end{tabular}

Different letters indicate significant difference between means at $\mathrm{P}<0.05$

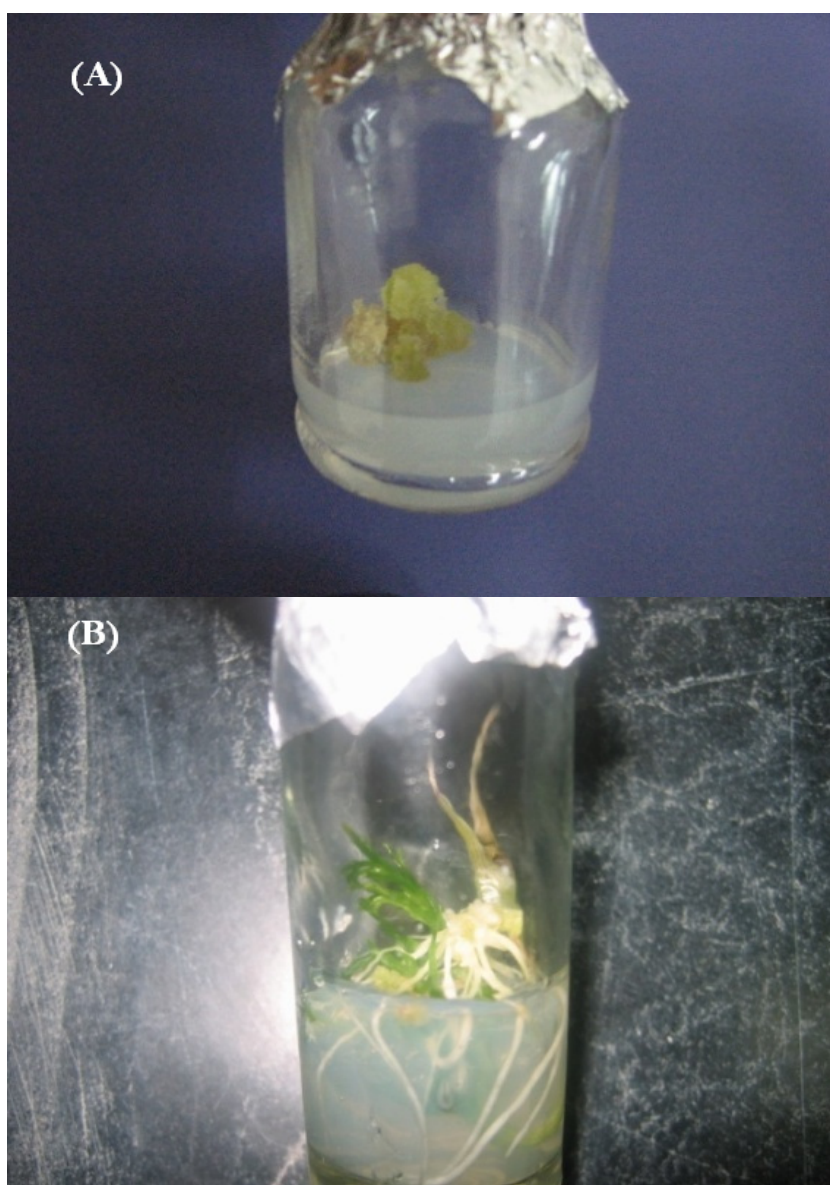

Fig. 1. (A) Induction of callus from the cotyledon of Foeniculum vulgare on MS media containing $1 \mathrm{mg} \mathrm{l}^{-1}$ IAA plus $1 \mathrm{mg}$ $\mathrm{l}^{-1} 2,4-\mathrm{D}$ and $2 \mathrm{mg} \mathrm{l}^{-1}$ kinetin. (B) Regeneration from the callus of Foeniculum vulgare on MS media containing $2 \mathrm{mg} \mathrm{l}^{-1} \mathrm{NAA}$ and $0.5 \mathrm{mg} \mathrm{l}^{-1}$ kinetin

\section{Callus induction capacity in different explants under salinity stress}

The callus induction from different explants was assessed to $\mathrm{NaCl}$ salt stress. The callus induction rates were 29.91, 87.81 and 93.34\% respectively, for root, hypocotyl and cotyledon explants under salinity stress (Tab. 2). This indicated a significant differential explants ability for callus induction, with root being less responsive than cotyledon, which appears as the best explant for in vitro tissue culture. The callus induction efficiency differed significantly $(\mathrm{p}<0.05)$ between the different explants at each of the tested salt stress levels (Tab. 2). At higher salt stress levels the explants of hypocotyl and cotyledon reacted moderately, while root showed a sharp decrease in the callus induction capacity, reaching $5 \%$ at $150 \mathrm{mM} \mathrm{NaCl}$ (Fig. 3 and 4). Mean Comparisons of data for callus induction efficiency in different treatments of salinity is presented in Tab. 3. Callus induction efficiency was low for differential explants at higher salt stress levels compared to mild stress levels $(50 \mathrm{mM})$, but no sizeable differences were observed between the control treatment and $50 \mathrm{mM} \mathrm{NaCl}$ (Tab. 3). The results show that under control conditions and 150 

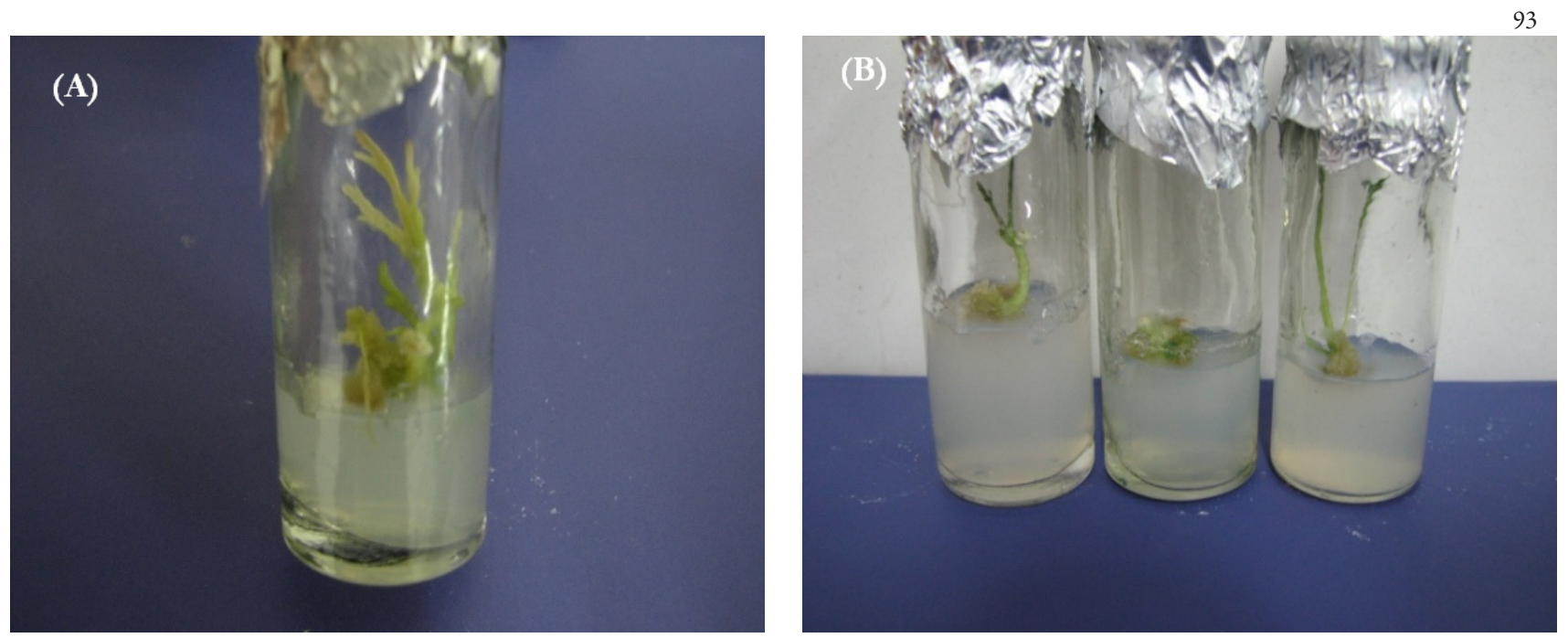

Fig. 2. Shoot regeneration of Foeniculum vulgare from the callus grown on MS media containing $2 \mathrm{mg} \mathrm{l}^{-1} \mathrm{NAA}$ and $0.5 \mathrm{mg} \mathrm{l^{-1 }} \mathrm{kinetin}$ in presence of (A) $50 \mathrm{mM} \mathrm{NaCl}$ and (B) $100 \mathrm{mM} \mathrm{NaCl}$

$\mathrm{mM}$ of treatments of salt stress, callus induction rates were $84.17 \%$ and $49.79 \%$, respectively. Therefore, in the presence of $150 \mathrm{mM} \mathrm{NaCl}$, the percentage of calli induction was decreased with $41 \%$ (Tab. 3). Results from different treatments, with different concentrations of $\mathrm{NaCl}$, showed
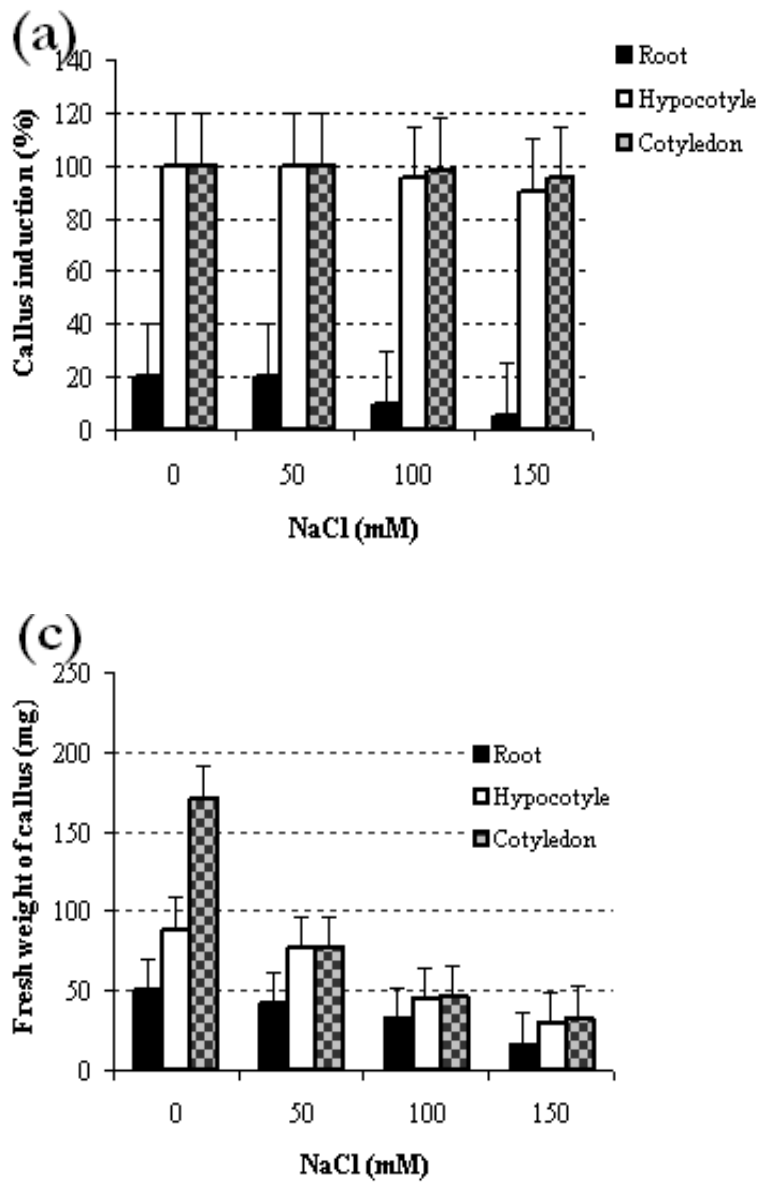

that proliferation rate of calli decreased when concentrations of $\mathrm{NaCl}$ increased in the both media (Fig. 3 and 4).
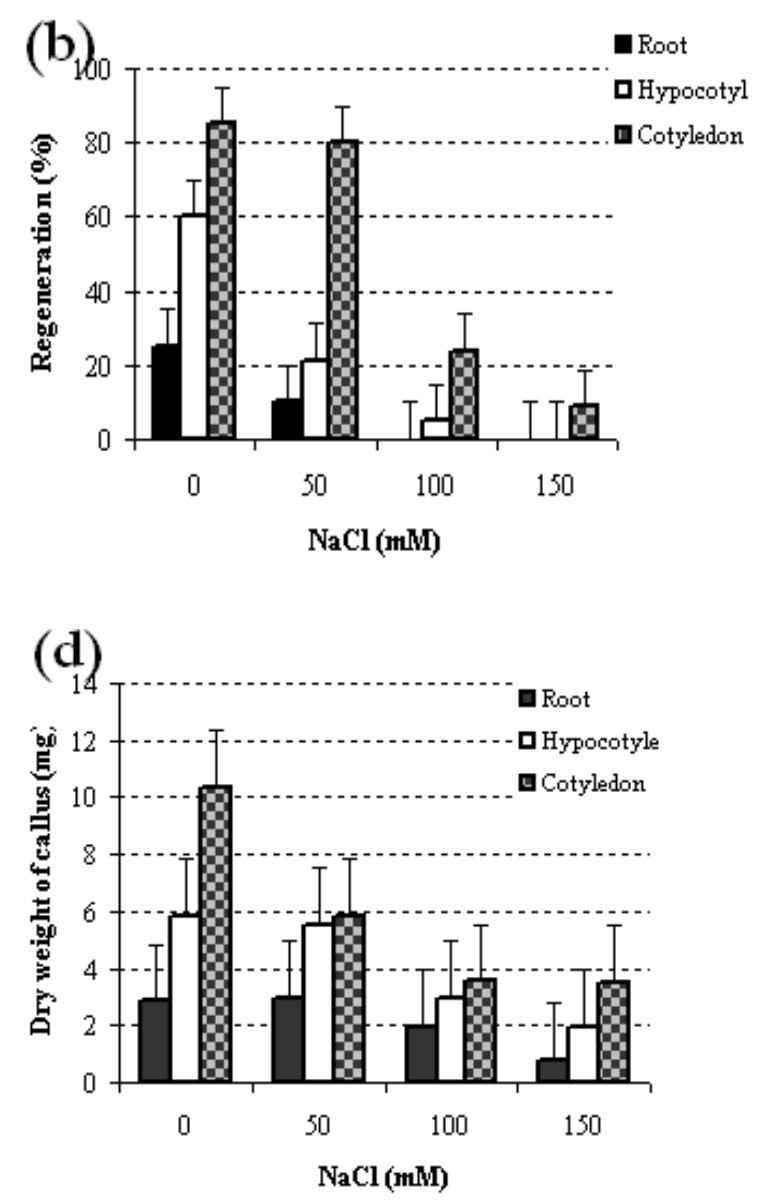

Fig. 3. Interaction effect salinity and explants on (a) callus induction, (b) shoot regeneration, (c) fresh weight and (d) dry weight of Foeniculum vulgare on MS medium containing $2 \mathrm{mg} \mathrm{l}^{-1} \mathrm{NAA}$ and $0.5 \mathrm{mg} \mathrm{l}^{-1}$ kinetin (media II) 
Tab. 4. Analysis of variance for studied traits of Foeniculum vulgare under salinity stress

\begin{tabular}{|c|c|c|c|c|c|}
\hline $\begin{array}{l}\text { Dry weight } \\
\text { of callus (mg) }\end{array}$ & $\begin{array}{c}\text { Fresh weight of } \\
\text { callus }(\mathrm{mg})\end{array}$ & $\begin{array}{c}\text { Shoot regeneration } \\
\text { frequency }(\%)\end{array}$ & $\begin{array}{c}\text { Callus induction } \\
\text { frequency }(\%)\end{array}$ & $\begin{array}{c}\text { Degrees of } \\
\text { freedom }\end{array}$ & Source of variation \\
\hline $97.83^{* *}$ & $24382.78^{* *}$ & ${ }^{* *} 6355.40$ & $12666.24^{* *}$ & 23 & Treatment \\
\hline 10ns & $13160.93^{* *}$ & ${ }^{* *} 16328.32$ & $16.81 \mathrm{~ns}$ & 1 & Media \\
\hline $320.70^{* *}$ & $105090.27^{* *}$ & ${ }^{* *} 17111.70$ & $21560.62^{* *}$ & 3 & Salinity \\
\hline $496.46^{* *}$ & $69407.52^{* *}$ & ${ }^{* *} 26080.85$ & $91687.21^{* *}$ & 2 & Explant \\
\hline $0.157 \mathrm{~ns}$ & $391.12 \mathrm{~ns}$ & $* * 4532$ & $6044.73^{* *}$ & 3 & Salinity $\times$ Media \\
\hline $14.69^{*}$ & $3045.33 \mathrm{~ns}$ & ${ }^{* *} 480.94$ & $9780.18^{* *}$ & 2 & Media $\times$ Explant \\
\hline $37.37^{* *}$ & $11777.85^{* *}$ & ${ }^{* *} 1666.72$ & $540.60^{* *}$ & 6 & Salinity $\times$ Explant \\
\hline $5.17 \mathrm{~ns}$ & $2604.3^{* *}$ & ${ }^{* *} 298.51$ & $385.36^{* *}$ & 6 & Salinity $\times$ Explant $\times$ Media \\
\hline 3.25 & 641.53 & 6.83 & 11.25 & 336 & Error \\
\hline
\end{tabular}

*, **: Significant difference at 0.05 and 0.0.1 probability level, respectively; ns: Not significant.

\section{Plant regeneration response to $\mathrm{NaCl}$ stress}

After callus proliferation on MS based medium with different concentration of plant growth regulators, calli were then subcultured on the same medium with concentrations of $0,50,100$ and $150 \mathrm{mM}$ of $\mathrm{NaCl}$ for 28 days. Most of the calli become brown and died in the present of 100 and $150 \mathrm{mM} \mathrm{NaCl}$. In the case of shoot regeneration at salt stress conditions, all the calli responded better on MS medium containing $2 \mathrm{mg} \mathrm{l}^{-1} \mathrm{NAA}$ and $0.5 \mathrm{mg} \mathrm{l}^{-1} \mathrm{ki}-$

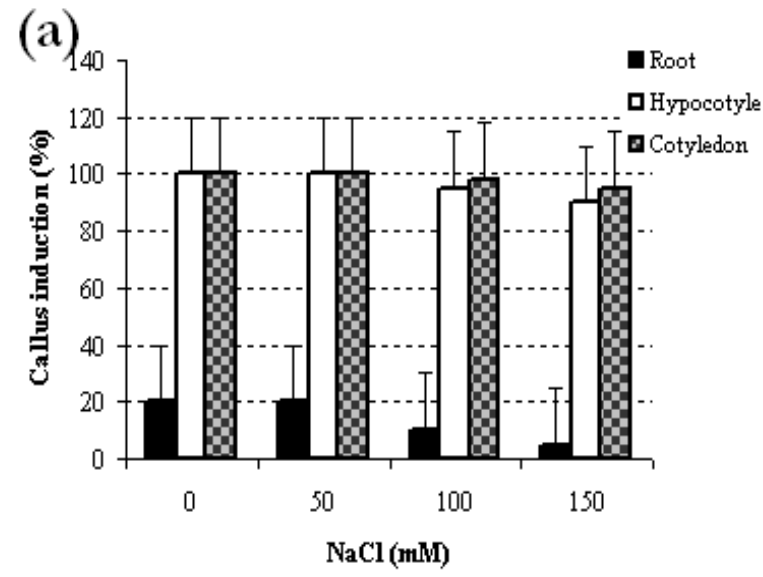

(c)

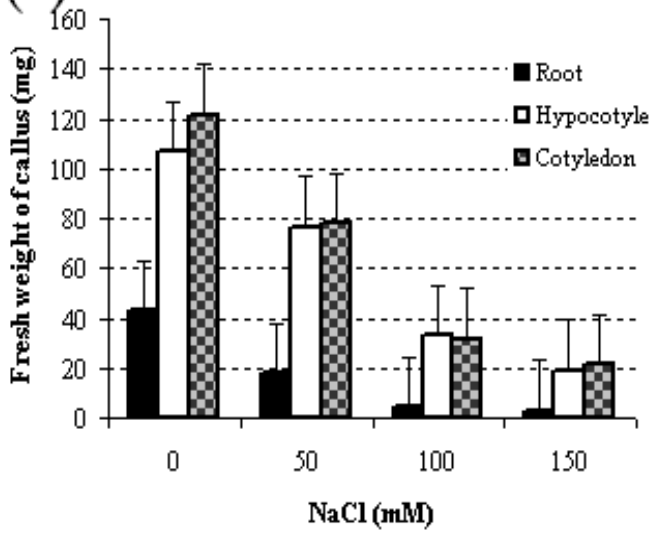

netin (media II) compared to media (I) consisting of MS medium supplemented with $1 \mathrm{mg} \mathrm{l}^{-1}$ IAA plus $1 \mathrm{mg} \mathrm{l}^{-1} 2,4-$ $\mathrm{D}$ and $2 \mathrm{mg} \mathrm{l}^{-1}$ kinetin.

Callus of root, hypocotyl and cotyledon explants on media (I) did not produce any shoot regeneration in the presence of $150 \mathrm{mM} \mathrm{NaCl}$ (Fig. 4), while regeneration rate of the proliferated calli of explant of cotyledon on media (II) was $8.75 \%$ under $150 \mathrm{mM}$ salt stress (Fig. 3). Also, there was no shoot regeneration above $100 \mathrm{mM} \mathrm{NaCl}$ on
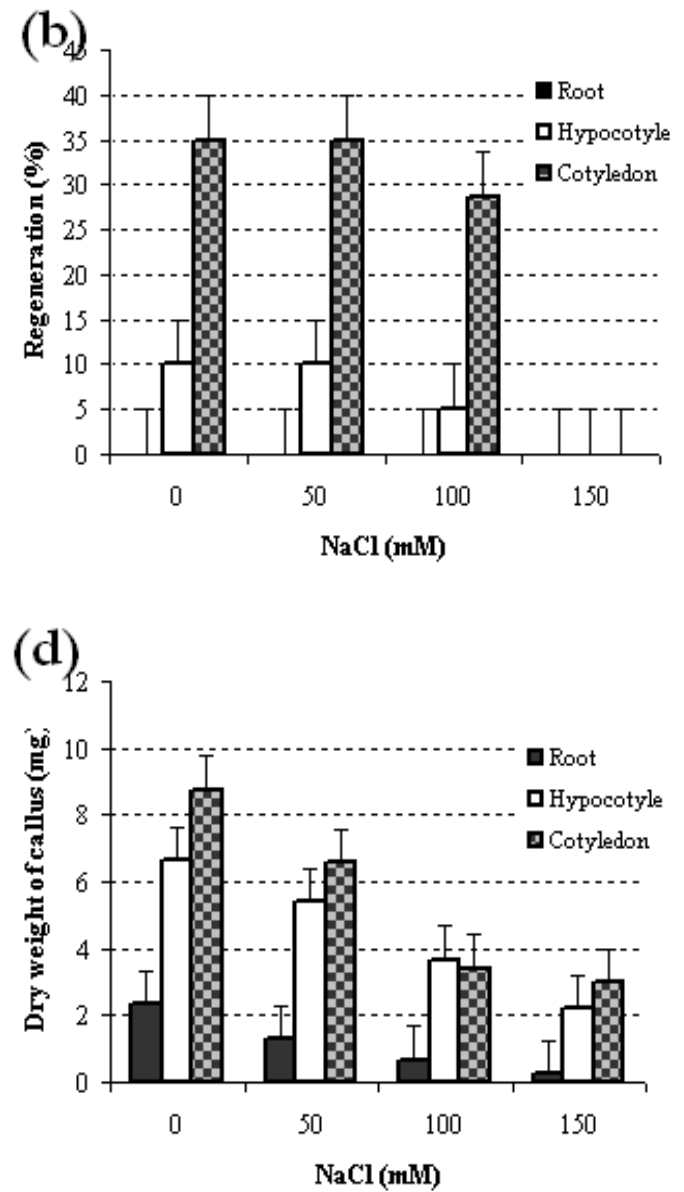

Fig. 4. Interaction effect salinity and explants on (a) callus induction, (b) shoot regeneration, (c) fresh weight and (d) dry weight of Foeniculum vulgare on MS medium containing $1 \mathrm{mg} \mathrm{l}^{-1}$ IAA plus $1 \mathrm{mg} \mathrm{l}^{-1} 2,4-\mathrm{D}$ and $2 \mathrm{mg} \mathrm{l}^{-1}$ kinetin (media I) 
the explants of root and hypocotyl, in both media. Therefore, the explants of cotyledon exhibited a higher tolerance to the $\mathrm{NaCl}$ treatment, in vitro, in comparison with the other explants (Fig. 3). Mean Comparisons showed that the highest regeneration efficiency was achieved under control conditions $(35.83 \%)$, whereas, the lowest regeneration efficiency were observed under $150 \mathrm{mM} \mathrm{NaCl}$ (1.46\%). Therefore, in presence of $150 \mathrm{mM} \mathrm{NaCl}$, the regeneration was decreased about $96 \%$ (Tab. 3). However, the increased concentrations of $\mathrm{NaCl}$ in the medium led to a decrease of the regeneration in both media; the most decreasing one was obtained on above $50 \mathrm{mM} \mathrm{NaCl}$. Results of the analysis of variance for regeneration percentage showed significant differences among different treatments of salinity, explants and interaction effect of salinity $\times \mathrm{ex}$ plants at 0.05 level (Tab. 4).

\section{Salinity effect on callus growth}

Salt treatments significantly $(\mathrm{P}<0.005)$ affected the growth rate of callus (Tab. 3). Results of compared mean of fresh and dry weight in different concentrations of salinity showed that there was a significant difference between treatments in the $5 \%$ level (Tab. 4). Callus in different salt treatments exhibited different growth rates. Callus growth was significantly inhibited by salinity treatments. Although $50 \mathrm{mM} \mathrm{NaCl}$ treatment showed the highest growth rate among the different treatments, it was lower than that of control callus (Tab. 3). At 100 and $150 \mathrm{mM}$ $\mathrm{NaCl}$ treatments the callus growth rate (at both mediums) was much lower than that of control or $50 \mathrm{mM} \mathrm{NaCl}$ treatment. The lower fresh and dry weights in all calli were observed in $150 \mathrm{mM} \mathrm{NaCl}$ (Fig. 3 and 4). The results showed that cotyledon explants had maximum and root explants had minimum of fresh and dry weight in different treatments of salinity (Tab. 2). The highest growth rate was observed in cotyledon explants under $150 \mathrm{mM} \mathrm{NaCl}$. Also, in MS medium supplemented with $2 \mathrm{mg} \mathrm{l}^{-1} \mathrm{NAA}$ and 0.5 $\mathrm{mg}^{\mathrm{l}^{-1}}$ kinetin (media II) and different concentration of $\mathrm{NaCl}$, callus exhibited better growth rate than that of MS medium containing $1 \mathrm{mg} \mathrm{l}^{-1}$ IAA plus $1 \mathrm{mg} \mathrm{l}^{-1} 2,4-\mathrm{D}$ and 2 $\mathrm{mgl}^{-1}$ kinetin (media I).

\section{Discussion}

There are a number of reports regarding in vitro regeneration and callus induction of fennel by using various explants such as hypocotyl or stem explants (Bennici et al., 2004). Besides, Anzidei et al. (1996) reported that callus induction and organogenic response of several fennel populations were clearly genotype and growth regulator dependent. Only a variety, Francia Pernod, gave a good response for callus formation in the presence of 2,4-D or NAA plus kinetin, and shoot regeneration induced by NAA and kinetin. Therefore, in previous studies conducted on fennel, the highest frequency of shoot regeneration was found in callus lines growing in the presence of NAA and kinetin at 1:1 ratio and after a callus culture period of
9 months (Anzidei et al., 2000). While in this research, the highest frequency of shoot regeneration from hypocotyl and cotyledon explants was obtained when the NAA and kinetin were used at a 4:1 ratio after a period of one month. Thus, it can reduce the time and cost of the experiment. In fact, for several species, studies have showed that many factors, such as the medium composition, genotype, and the type of explant, affects the callus induction and plant regeneration processes. In the present study the variation noted in the callus induction capacity and plant regeneration appears to be mainly due to the explant and the medium composition effect.

The deleterious effects of salinity on plants are attributed to the reduction of water absorption by roots, ion toxicity and disturbed ionic balances. The drastic increase in the concentration of $\mathrm{Na}^{+}$and $\mathrm{Cl}^{-}$in tissues, following plant exposure to salinity, led to toxicity as it was evidenced by reduced plant growth (Greenwey and Munns, 1980; Tester and Davenport, 2003; Karimi et al., 2009). Ionic toxicity occurs because of the high concentrations of $\mathrm{Na}^{+}$and $\mathrm{Cl}^{-}$in the cells' cytoplasm, which disturb several biochemical and physiological processes, and therefore osmotic stress is induced by the lowering of the water potential causing turgor reduction and cellular water loss (Jampeetong and Brix, 2009). In this research, salinity decreased plant growth significantly. These findings are compatible with those obtained on cotton (Ashraf and Ahmad, 2000), lentil (Misra and Saxena, 2009), Salvinia natans (Jampeetong and Brix, 2009). Increasing $\mathrm{NaCl}$ concentration in the medium caused a significant reduction in fresh weight of both shoots and roots, as well as dry weight. Rafiq et al. (2008) reported that the calli fresh and dry weights of local mungbean decreased as the concentration of $\mathrm{NaCl}$ increased in the medium. Under stress condition, one of the strategies that plants have adopted is to slow down their growth. This reduction in growth not only helps the plant to save the energy for the defence purpose, but also limits the risk of heritable damage (May et al., 1998; Hossain et al., 2007). Root growth has been found to be more adversely affected than shoot growth by an increasing supply of $\mathrm{NaCl}$ (Cano et al., 1998). Similar results were obtained in this work, although root, hypocotyl and cotyledon growth were inhibited by salt, the effects were more pronounced on root growth. Results showed that salinity stress applied to in vitro cultures reduced the regeneration ability and callus induction at Foeniculum vulgare. The obtained results are in agreement with those reported by Rafiq et al. (2008) for local mungbean and Binch et al. (1992) for rice. Khaleda et al. (2007) also showed the decreasing trend in callus proliferation and plant regeneration with the increasing concentrations of $\mathrm{NaCl}$ in deep-water rice. The decrease in regeneration frequency in $\mathrm{NaCl}$-selected callus line may be due to the presence of $\mathrm{NaCl}$ in the regeneration medium (Hossain et al., 2007). As Makhlouf et al. (2002) reported, the decrease of the osmotic potential of the culture medium caused a decreasing regeneration in Sorghom (Sorghom bicolor L.) 
96

under in vitro selection. Therefore, $\mathrm{NaCl}$ has an inhibitory effect on plant growth by lowering the water potential of the medium, so cultured explants are unable to take up water and nutrients from the medium. Salt stress simultaneously presents both an ionic component linked to the toxicity of high external amounts of Sodium and Chloride ions, and a hydric component linked to the decrease of the external osmotic potential. The finding of regeneration decrements in the present study were in agreement with many researchers who reported negative response of $\mathrm{NaCl}$ towards plant regeneration. Gonzalez et al. (2001) mentioned that $\mathrm{NaCl}$ inhibited plant regeneration. Also, Lutt's et al. (1999) reported that salinity strongly reduced the regeneration capacities of callus obtained from all cultivars and on all regeneration media tested, which is an agreement with the present study. In this experiment, it was revealed a high difference among explants in their callus production ability and in plant regeneration rate. Explants of root, hypocotyl cultured on medium containing $150 \mathrm{mM} \mathrm{NaCl}$ showed no shoot regeneration, while cotyledon showed regeneration in the presence $150 \mathrm{mM} \mathrm{NaCl}$. These results indicated that calli induction and regeneration were explants, medium composition and genotype dependent, which are in agreement with the data found on alfalfa (Safarnejad et al., 1996), durum wheat (Ozgen et al., 1996) and local mungbean (Rafiq et al.,2008), where the effects of explants, medium composition and genotype on calli induction capacity and regeneration frequencies was observed.

The selected callus line exhibited several positive characters (better growth, higher regeneration frequency) towards salinity stress. This might be the result of some small changes in genetic makeup (somaclonal variation), of which several are beneficial for salt resistance. However, further studies need to be undertaken to resolve this issue. A possible strategy for finding the solution of the problems arising from salinization of agricultural and horticultural soils could be the in vitro selection of tolerant plants (Morpurgo, 1991). In vitro culture can be used to obtain salinity-tolerant plants, assuming that there is a correlation between cellular and in vivo plant responses (Smith $e t$ al., 1985). Selections of favorable somaclonal variant strains from callus culture are supplementary tools to traditional breeding for production of stress-resistant plants (Larkin and Scowcroft, 1981; Ashraf, 1994). Therefore, in vitro tissue culture could serve as an important mean to improve crop tolerance and yield through genetic transformation, as well as induced somaclonal variation. It is important to device an efficient protocol of callus proliferation in order to start in vitro selection for salt and stress tolerance, and to broaden the opportunities for genetic manipulation of medicinal plants through tissue culture, including trying various explants and media.

\section{Acknowledgements}

The authors wish to thank the Agriculture and Natural Resources Research Center of Razavi Khorasan and Islamic Azad University of Mashhad, Iran, for funding this research.

\section{References}

Alvarez I, Tomaro LM, Benavides PM (2003). Changes in polyamines, proline and ethylene in sunflower calluses treated with NaCl. Plant Cell Tiss Org Cult 74(1):51-59.

Anzidei M, Vivona L, SchiffS, Bennici A (1996). In vitro culture of Foeniculum vulgare: callus characteristics in relation to morphogenesis. Plant Cell Tissue and Organ Culture 45(3):263-268.

Anzidei M, Bennici A, Schiff S, Tani C, Mori B (2000). Organogenesis and somatic embryogenesis in Foeniculum vulgare: histological observations of developing embryogenic callus. Plant Cell Tiss Org Cult 61:69-79.

Ashraf, M (1994). Breeding for salinity tolerance in plants. Crit Rev Plant Sci 13:17-42.

Ashraf M, Ahmad S (2000). Influence of sodium chloride on ion accumulation, yield components and fibre characteristics in salt-tolerant and salt-sensitive line of cotton (Gossypium hirsutum L.). Field Crops Research 66:115-127.

Barakat MN, Abdel-LatifTH (1996). In vitro selection of wheat callus tolerant to high levels of salt and plant regeneration. Euphytica 91:127-140.

Benderradji L, Bouzerzou $\mathrm{H}$, Djekoun A, Yekhlef $\mathrm{N}$, Benmahammed A (2007). Effects of $\mathrm{NaCl}$ stress on callus proliferation and plant regeneration from mature embryos of bread wheat (Triticum aestivum L.) cultivars Mahon Demias and Hidhab. Plant Tiss Cult Bio 17(1):19-27.

Bennici A, Anzidei M, Vendramin GG (2004). Genetic stabitity and uniformity of Foeniculum vulgare Mill. regenerated plants through organogenesis and somatic embryogenesis. Plant Science 166:221-227.

Binch DQ, Heszky LE, Gyulai G, Csillag, A (1992). Plant regeneration of $\mathrm{NaCl}$ pretreated cells from long-term suspension culture of rice (Oryza sativa L.) in high saline conditions. Plant Cell Tiss Org Cult 29:75-82.

Cano EA, Perez-Alfocea F, Moreno V, Caro M, Bolarin MC (1998). Evaluation of salt tolerance in cultivated and wild tomato species through in vitro shoot apex culture. Plant Cell Tiss Org Cult 53:19-26.

Damjanovic B, Lepojevic Z, Zivkovic V, Tolic A (2005). Extraction of fennel (Foeniculum vulgare Mill.) seeds with supercritical $\mathrm{CO}_{2}$ : Comparison with hydrodistillation. Food Chemistry 92:143-149.

Dennis Thomas T, Sreejesh KR (2004). Callus induction and plant regeneration from cotyledonary explants of ash gourd (Benincasa hispida L.). Scie Hort 100:359-367. 
Ganeshan S, Baga M, Harwey BL, Rossnagel BG, Scoles GJ, Chibbar RN (2003). Production of multiple shoots from thiadiazuron-treated mature embryos and leaf base/apical meristems of barley (Hordeum vulgare L.). Plant Cell Tiss Org Cult 73:57-64.

Gandonou C, Abrini J, Idaomar M, Skali Senhaji N (2005). Response of Sugarcane (Saccharum sp.) varieties to embryogenic callus induction and in vitro salt stress. African Journal of Biotechnology 4(4):350-354.

Greenwey H, Munns R (1980). Mechanism of salt tolerance in nonhalophyte. Ann Rev Plant Physiol 31:149-190.

Gonzalez JM, Friero E, Jouve N (2001). Influence of genotype and culture medium on callus formation and plant regeneration from immature embryos of Triticum turgidum Desf. cultivars. Plant Breeding 120:513-517.

Hossain Z, Mandal AKA, Datta SK, Biswas AK (2007). Development of $\mathrm{NaCl}$-tolerant line in Chrysanthemum morifolium Ramat. Through shoot organogenesis of selected callus line. Journal of Biotechnology 129:658-667.

Jampeetong A, Brix H (2009). Effects of $\mathrm{NaCl}$ salinity on growth, morphology, photosynthesis and proline accumulation of Salvinia natans. Aquatic Botany 91:181-186.

Jiang W, Cho MJ, Lemaux PG (1998). Improved callus quality and prolonged regenerability in model and recalcitrant barley (Hordeum vulgare L.) cultivars. Plant Biotechnology 15:63-69.

Karimi E, Abdolzadeha A, Sadeghipour HR (2009). Increasing salt tolerance in olive, Olea europaea L. plants by supplemental potassium nutrition involves changes in ion accumulation and anatomical attributes. Internat J Plant Prod 3(4):49-60.

Khaleda L, Ahmad AMA, Marzan LW, Al-Forkan M (2007). Identification of callus induction and plat regeneration responsiveness in presence of $\mathrm{NaCl}$ in in vitro culture of some deepwater rice (Oryza sativa L.) cultivars. Asian Jurnal of Plant Sciences 6: 6-41.

Larkin PJ, Scowcroft SC (1981). Somaclonal variation a noval source of variability from cell culture for plant improvement. Theoretical and Applied Genetics 60:197-214.

Lutt's S, Kinet JM, Bouharmont J (1999). Improvement of rice callus regeneration in the presence of $\mathrm{NaCl}$. P Plant Cell Tiss Org Cult 57:3-11.

Mahajan S, Tuteja N (2005). Cold, salinity and drought stresses: An overview. Archives of Biochemistry and Biophysics 444:139-158.

May MJ, Vernoux T, Leaver C, Van Montagu M, Inze D (1998). Glutathione homeostasis in plants: implications for environmental sensing and plant development. J Exp Bot 49:649-667.

Makhlouf A, Mabrouk Y, El-Saied M, Mahdy M (2002). In vitro selection for drought tolerance in Sorghum (Sorghum bicolor L.) and regeneration evaluation of selected genotypes. Alex J Agricult Res 47:77-88.
Mohamed MAH, Harris PJC, Henderson J (2000). In vitro selection and characterization of a druogh tolerant clone of Tagetes minuta. Plant Science 159:213-222.

Misra N, Saxena P (2009). Effect of salicylic acid on proline metabolism in lentil grown under salinity stress. Plant Science 177:181-189.

Morpurgo R (1991). Correlation between potato clones in vivo and in vitro under sodium chloride stress conditions. Plant Breed 107:80-82.

Murashing T, Skoog F (1962). A revised medium for rapid growth and bioassay with tobacco tissue culture. Physiologia Plantarum 15:473- 497.

Ozgen M, Tiiret M, Ozcan S, Sancak C (1996). Callus induction and plant regeneration from immature and mature embryos of winter durum wheat genotypes. Plant Breeding 115:455458.

Piccaglia R, Marotti M (2001). Characterization of some Italian types of wild fennel (Foeniculum vulgare Mill.). Journal of Agricultural and Food Chemistry 49:239-244.

Rafiq M, Mali M, Khatri A, Dahot MU (2008). Callus induction and regeneration in local mungbean (Vigna radiate $\mathrm{L}$. Wilczek) under salt stress. Journal of Biotechnology 136:147-169.

Sabbah S, Tal M (1990). Development of callus and suspension cultures of potato resistant to $\mathrm{NaCl}$ and mannitol and their response to stress. Plant Cell Tiss Org Cult 21:119-128.

Safarnejad A (2004). Characterization of somaclones of alfalfa (Medicago sativa L.) for drought tolerance. J Agric Sci Technol 6:121-127.

Safarnejad A, Collin H, Bruce KD, McNeilly T (1996). Characterization of alfalfa following in vitro selection for salt tolerance. Euphytica 92:55-61.

Sibi ML, Fakiri M (2000). Androgenèse et gynogenèse, sources de vitro variation et de tolérance à la salinité chez l'orge Hordeum vulgare. Note de recherche Sécheresse 11(2):125132.

Smith RH, Bhaskaran S, Miller FR (1985). Screening for drought tolerance in sorghum using cell culture. In vitro Cell Dev Biol 21: 541-545.

Tester M, Devenport R (2003). $\mathrm{Na}^{+}$tolerance $\mathrm{Na}^{+}$transport in higher plants. Annal Bot 91:503-527.

Yokoi S, Bressan A, Hasegawa PM (2002). Salt stress tolerance of plants. JIRCAS Working Report 25-33.

Zalc JM, Wicr HB, Kidwell KK, Steber CM (2004). Callus induction and plant regeneration from mature embryos of a diverse set of wheat genotypes. Plant Cell Tiss Org Cult 76:277-281.

Zhu JK (2007). Plant salt stress. In: Encyclopedia of Life Sciences. John Wiley and Sons, Ltd: Chichester www. Els. Net. 